\title{
THE EFFECT OF JOB SATISFACTION ON GENERATION Y EMPLOYEES' PERFORMANCE WITH MOTIVATION AS THE INTERVENING VARIABLE AT THE GENERAL SECRETARIAT OF THE MINISTRY OF AGRICULTURE
}

\author{
Indriani Ayu Septi ${ }^{1 *}$, Panjaitan Nurmala K. ${ }^{2}$, Kuswanto Sadikin ${ }^{1}$ \\ ${ }^{1}$ School of Business, Bogor Agricultural Institute, Bogor, Indonesia \\ ${ }^{2}$ Faculty of Human Ecology, Bogor Agricultural Institute, Bogor, Indonesia \\ *E-mail: ayusepti.indriani@gmail.com
}

\begin{abstract}
In order to achieve an organization' goal, the employees should provide maximum performance. Instead of only one generation, an organization is usually filled with several generations; one of them is the generation $Y$. More generations $Y$ start to enter the job world while bringing values different from their previous generation. In order to overcome such problem, human resource development should be prepared soon, in which the excessive number of productive age population can be used to improve the development. Based on the facts above, this research aimed to analyze the effect of Job satisfaction on performance with motivation as the intervening variable. The respondents of this research are the General Secretariat of The Ministry of Agriculture employees who belong to the generation $Y$ with the age range of 23-37 years old. There were 74 employees act as the respondents of this research taken from the accidental sampling method. The method used in this research was Structural Equation Model (SEM) through Partial Least Square (PLS) approach using the application of Smart PLS 2.0. The result of this research obtained that the employees' job satisfaction positively and significantly affect the employees' performance through their motivation. Motivation can function as an intervening variable to affect the employees' job satisfaction on their performance in which the higher the generation $Y$ employees' job satisfaction, the more increase their motivation which gives positive and direct effect on improving their performance in the Secretariat General of the Ministry of Agriculture.
\end{abstract}

\section{KEY WORDS}

Generation Y, employees, job, satisfaction, motivation, performance.

Human resources play an important role in all business operational activities starting from the planning, implementation, and evaluation. One of the roles of the human resources is to relate the strategy and the business activities as a whole (Marhari et al. 2013). Sustainable management of human resource must be conducted through the planning of the organization which involves the human resources from various generations. This is such an important thing to be considered by an organization, since an organization is not filled with one generation only, but several generations. The differences between the generations also become a problem encountered by the management of human resources (Sajjadi et al. 2012).

According to the Statistics Indonesia (2017) workers are dominated by generation $X$ by $43.28 \%$, generation $Y$ by $40.77 \%$ and baby boomers by $15.95 \%$ of the total workers' population. Such composition explains sufficiently how the current condition of the government agencies is. However, the generation $\mathrm{Y}$ involvement in the government agencies will continuously to grow along the acceptance of Indonesian Government Officer candidates which have a classification of age limits ranging of 18-35 years. Currently, the proportion of generation $\mathrm{Y}$ entering the job world starts to increase who at the same time also bringing their distinctive values different from their previous generation. Such problem must be immediately overcome through human resources management in which the excessive number of productive age population can be used to increase the development.

The goal of the Secretariat General of the Ministry of Agriculture is to improve the performance accountability of the Ministry of Agriculture as well as coordinating, developing 
and supporting the administrative environment of the Ministry of Agriculture. The research result of the performance accountability evaluation in 2016 in the form of LAKIP conducted by the Ministry of Administrative and Bureaucratic Reform obtained that the Ministry of Agriculture is still in the BB value category meaning that it the employees still need to improve their performance. The following are the achievements of the Performance Accountability of the Government Agency of the Ministry of Agriculture in the past five years:

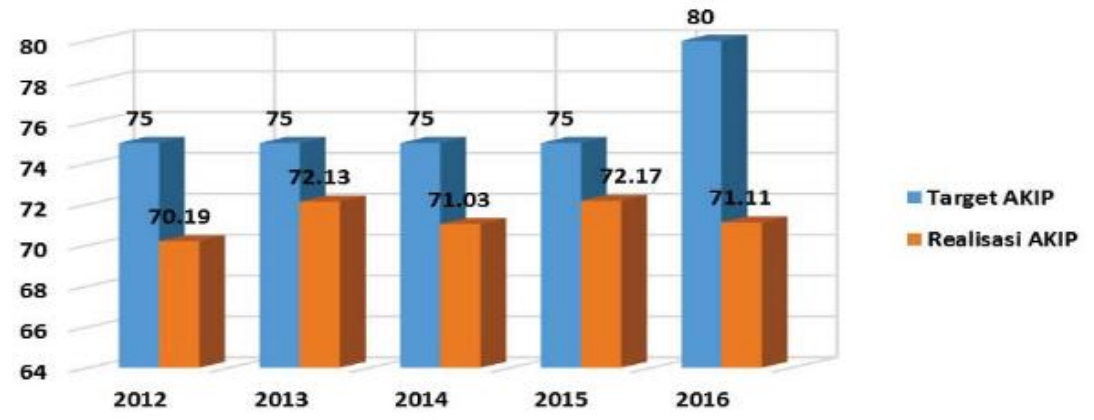

Figure 1 - Target and realization of the Ministry of Agriculture AKIP value in 2012-2016

(Source: Performance Report of the Secretariat General of the Ministry of Agriculture, 2017)

The performance report of the Secretariat General of the Ministry of Agriculture (2017) shows that the Ministry of Agriculture has not been able to achieve their intended AKIP value for the last five years (Fig 1). In addition, as one of the government agencies in the field of agriculture which focuses on serving the public, the quality value of the public service of the ministry should be paid attention. The Quality Score Indicator of Public Service achieved by the Ministry of Agriculture in 2017 obtained a result of 79.83 or $97.35 \%$ of 82 as the target, which means that the achievement of the Performance Indicator of the Public Service Satisfaction value of the Secretariat General of the Ministry of Agriculture has not achieved the target yet. Based on the preliminary observation and interview with the Organizational and Personnel Bureau of the Secretariat General of the Ministry of Agriculture, it indicates that the accumulation of employees' resignation and termination for the employees who belong to generation $Y$ has increased slightly. The cause can be in the form of less certainty that the generation $Y$ employees' characteristics or values systems are different from the previous generation so that it also requires different employees' policies.

Generation $Y$ is often considered as a job hopper or someone who likes to change jobs. In Gallup survey (2016), it was stated that millennial actually does not want to change their jobs, however, they often consider that their agency or company does not have any certain reason for them to keep working and giving the best performance on the same workplace. Generation $\mathrm{Y}$ is a young generation who pays attention more on the job's comfort working life balance. They have different characteristics, beliefs, work ethics, values, behavior, and work expectations in performing their roles in an agency or company (Niemiec 2000).

A government agency leader can make an effort to improve his human resources' performance by paying attention to the employees' job satisfaction and motivation. Job satisfaction is the starting point of the problems arise in the organization such as workerleader conflict and employees' turnover, while motivation can encourage oneself to manage their behavior in performing their duties and responsibilities (Panggalih and Zulaicha 2012). Therefore, it is necessary to conduct a further research on Generation Y. The objective of this study is to analyze the effect of generation $Y$ employees' job satisfaction on their performance with motivation as the intervening variable.

\section{LITERATURE REVIEW}

Human resources in an organization is basically a complicated problem since it involves individual problems. One of the characteristics which can cause poor working 
conditions in an organization is low job satisfaction. Gibson et al (2009) stated that job satisfaction is the employees' attitude resulting from their perceptions towards their work by considering the factors they found in the workplace environment such as supervisor style, policies and procedures, work group affiliation, working condition, and other benefits for the employees. According to Robbins (2006), job satisfaction is the employees' general attitude on their job. Robbins and Judge (2009) stated that there are five job satisfaction factors, including; (1) Satisfaction on the Job, (2) Satisfaction on the Rewards, (3) Satisfaction on the Supervision, (4) Satisfaction on the Colleagues, and (5) Opportunities or promotion.

Motivation is a condition where one makes an effort and willingness to directly achieve a certain result or goal (Sopiah 2008). Work motivation is a desire or encouragement from oneself which can cause, link, and support the employees' behavior to work diligently and enthusiastically in order to achieve their goals and perform well at work. Another important concept of motivation theory is based on the human's strength which is the achievement motivation. According to McClelland (1961), someone is considered to have motivation if he has a desire to perform better than the others. The aspects of achievement motivation include; (1) responsibility, (2) considering risks, (3) creative and innovative, (4) paying attention to feedback, (5) time to complete tasks, and (6) desires to be the best. An individual is more successful than the other individuals because they have a higher desire to achieve something. This desire gives them motivation to work more diligently (McClelland et al. 1953).

Employees' performance (work performance) is the quality and quantity result achieved by an employee in performing his duties and responsibilities (Mangkunegara 2009). Rivai and Basri (2005) provided an explanation that performance or work achievement is the result or the success level of a person as a whole during a certain period in performing his tasks compared in spite of various possibilities, such as work result standards, or targets that have been established and agreed previously. Performance assessment is a formal system in checking and reviewing employees' performance regularly. According to Barnard (1938) in Prawirosentono (2008), the employees' performance indicators include; (1) Effectiveness and Efficiency, (2) Authority and Responsibility, (3) Discipline, (4) Initiative.

According to Kupperschmidt (2000), generation $Y$ is persons who born in the same time range sharing the same historical experience and significant social life that shapes views and perspectives. Referring to the theory built by Oblinger and Oblinger (2005), generation $Y$ is a generation born in 1982-1999. Every generation in its era has its own natures and characteristics. Various similarities or differences between the generations can be used as a general description of how they behave. One of the most striking generations known for its diversity is Generation Y. Beu and Buckley (2001) explained that the generation $Y$ characteristics including of being creative and continuously learning aim to maintain their competitiveness, freedom, balance between the work life and personal life, work which is truly in accordance with his wishes and opportunities to develop their selves.

\section{METHODS OF RESEARCH}

This research was carried out from May to July 2018 at the Ministry of Agriculture Building $A$. The research method used in this research is qualitative and quantitative analysis through a case study approach. This research's sampling method used was accidental sampling. According to Nawawi (2001), accidental sampling is a technique where the sampling is not predetermined, but directly collecting the data from the sampling unit encountered. After the number of samples is sufficient, the researcher stopped the data collection. The research samples were obtained from the employees who are in accordance with the criteria and found during the research at the Secretariat General of the Ministry of Agriculture. This technique was chosen by the researchers because researchers have limited time and funds. The respondents of this research were the Generation $Y$ employees of the Secretariat General of the Ministry of Agriculture. Thus, the total respondents of this research were 74 employees. In addition, the researchers use Generation Y employees with the age ranges between 23-37 years old (Oblinger and Oblinger 2005) as the research samples. 
The questionnaire consists of 4 divisions by using a Likert scale. The first part is the respondents' characteristic. The second part consists of 5 indicators which reflect the job satisfaction factors (Robbins and Judge 2009). The third part consists of 6 indicators which reflect the employees' motivation (McClelland 1961). The fourth part consists of 4 indicators which describe the employees' work results (Barnard 1938 in Prawirosentono 2008). The analysis technique used was two different tests (ANOVA and t-test) to determine the scores' difference for each dimension in generation $Y$ as well as Partial Least Square-Structural Equation Modeling (SEM-PLS) using Smart PLS 2.0 software, a statistical technique that allows testing of a relatively complex set of relationships simultaneously. The implication of the research results is used as the basis for organizational management policy recommendations at the Secretariat General of the Ministry of Agriculture. The conceptual framework of this research can be seen in the following figure:

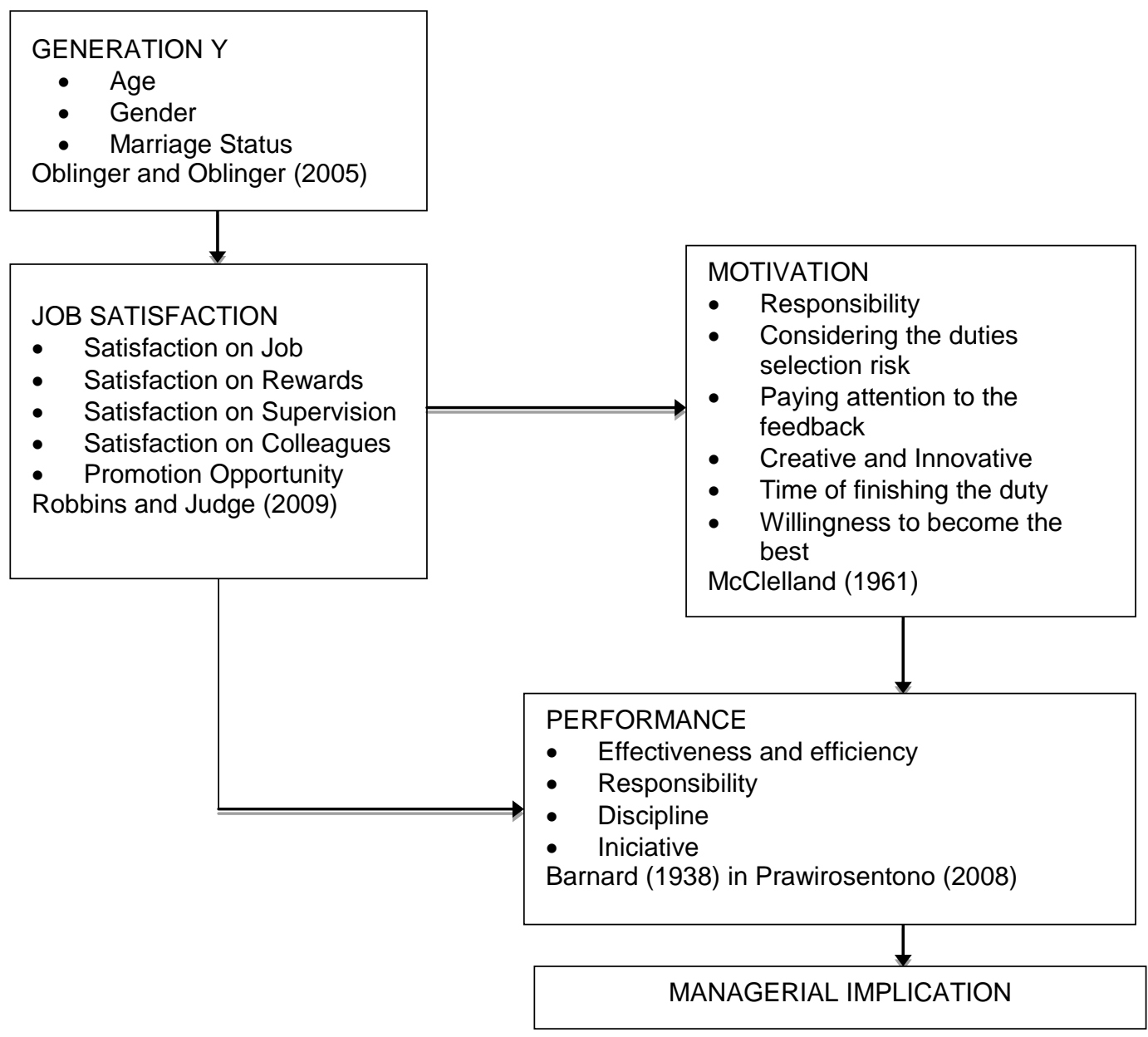

Figure 2 - Conceptual Framework of the Research

The research hypothesis proposed is:

- Hypothesis 1: Job satisfaction positively and significantly affects the motivation;

- Hypothesis 2: Job satisfaction positively and significantly affects the performance;

- Hypothesis 3: Motivation positively and significantly affects the performance;

- Hypothesis 4: Job satisfaction positively and significantly affects the performance through motivation.

\section{RESULTS AND DISCUSSION}

Respondents' Characteristics. Table 1 shows the profile of 74 respondents. Respondents in this research were $51.35 \%$ male and $48.65 \%$ female. This was not obtained 
intentionally, because the respondents were obtained not based on the gender differences. Based on the marriage status of the respondents, $81.08 \%$ is married, while the rest of $18.92 \%$ is unmarried. This is in line with $\mathrm{BKN}$ that the average age of Indonesians is married at 25 years (BKKBN 2013).

Table 1 - Respondents' Characteristics from Generation $Y$

\begin{tabular}{llll}
\hline & Respondents' Characteristics & Frequency (people) & Percentage (\%) \\
\hline \multirow{4}{*}{ Age } & $23-25$ years old & 5 & 6.76 \\
& $26-30$ years old & 15 & 20.27 \\
\multirow{3}{*}{ Gender } & $31-35$ years old & 43 & 58.11 \\
& $36-37$ years old & 11 & 14.86 \\
\multirow{2}{*}{ Marital status } & Man & 38 & 51.35 \\
& Women & 36 & 48.65 \\
Total & Single & 14 & 18.92 \\
& Married & 60 & 81.08 \\
\hline
\end{tabular}

The distribution of the respondents' age of 31-35 years old dominates the respondents for about $58.11 \%$ of the total respondents. Then, the age group of $26-30$ years old is dominating with a percentage of $20.27 \%$, the age group $36-37$ years old is around $14.86 \%$, and followed by the percentage of respondents in the age group of 23-25 years old in the least domination by around $6.76 \%$. It shows that the generation $\mathrm{Y}$ of the age group of 31-35 years old is dominating the respondents compared to the other age groups. According to informant opinion in the Secretariat General of the Ministry of Agriculture, generation $Y$ employees in this age group have more experience and expertise at work. Thus, it is expected that they will contribute their best performance for the Secretariat General of the Ministry of Agriculture. According to Zemke in Tolbize (2008) opinion, he suggested that Generation $\mathrm{Y}$ is considered has the ability to work in teams better, more cooperative, and more optimistic in the future.

The Effect of Job Satisfaction on Performance with Motivation as the Intervening Variable. Structural Equation Modeling Partial Least Square (SEM-PLS) consists of two submodels, those are the measurement model that shows how the manifest or observed variable represents a latent variable to be measured. Meanwhile, the structural model shows the estimation strength between the latent variables or constructs.

Measurement Model Evaluation. The measurement model in this study uses 15 indicators. If there are indicators that have a loading factor value of $<0.5$, a recalculation must be conducted of the initial model so that the loading factor of all reflective indicators is $>0.5$ as the criteria of the latent constructs convergent validity test (Ghozali 2008).

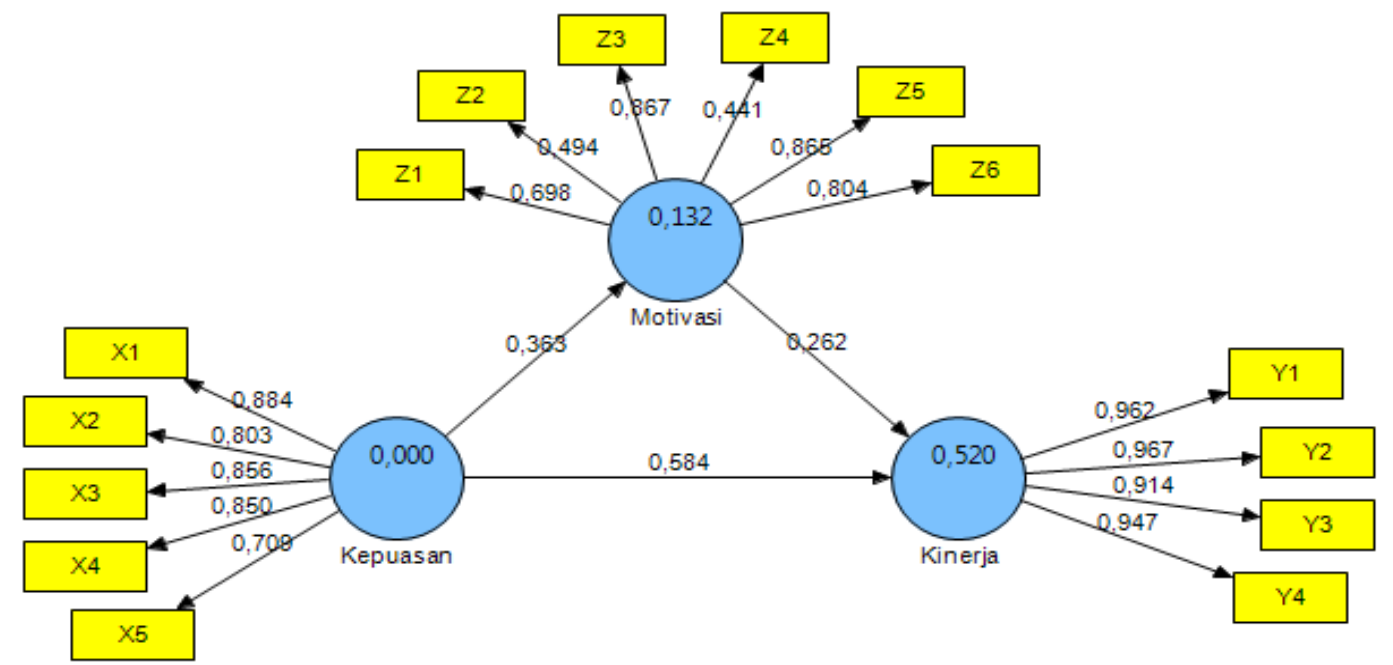

Figure 3 - The loading factor on the initial measurement model 
Figure 3 shows that there are indicators which have loading factor value $<0.5$, those are the loading factor value of considering the duties selection risk indicator which shows $Z_{2}$ of 0.494 and loading factor value of creative and innovative indicator which shows $Z_{4}$ of 0.441 . Therefore, it was necessary to do a recalculation on the model. After some calculations were done, the final SEM model obtained in Figure 4 shows that all indicators have a loading factor $>0.5$ and the convergent validity test for the latent constructs is fulfilled.

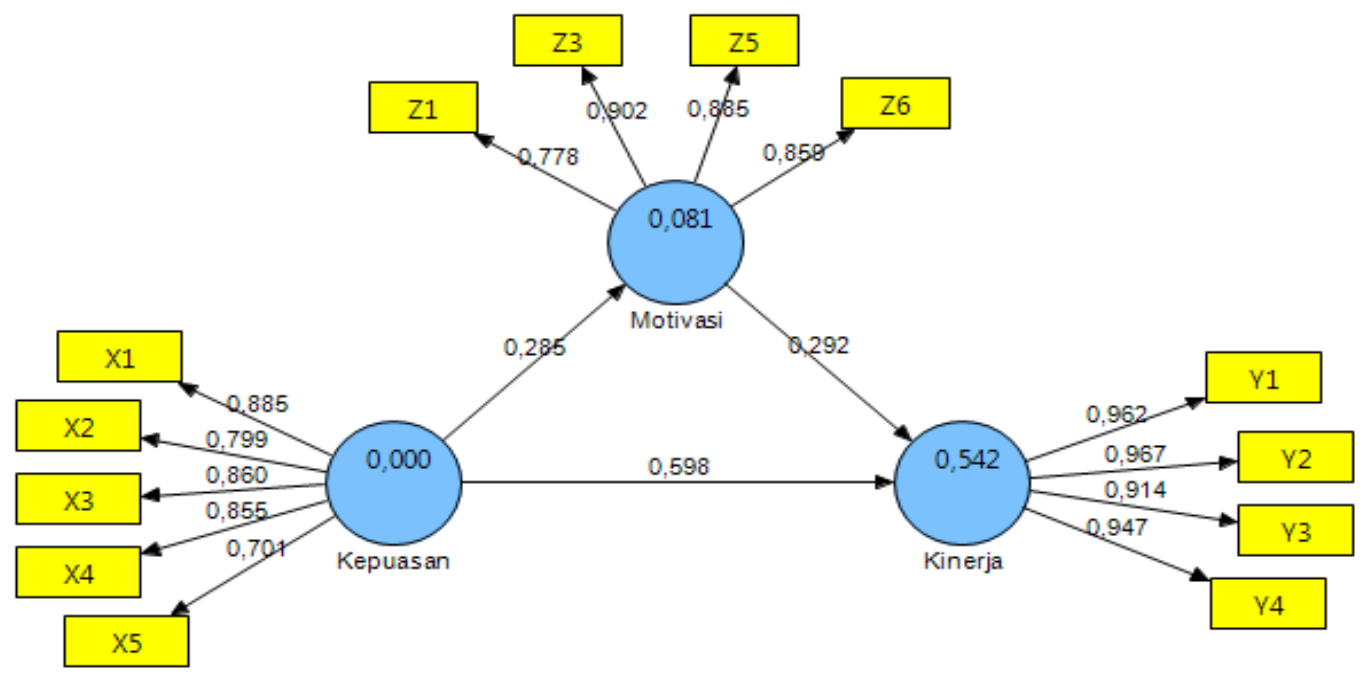

Figure 4 - The Loading factor in the final measurement model

Loading factors of the final measurement model shows that the indicators of the satisfaction on work and supervision are the highest two indicators reflecting that job satisfaction affecting the motivation and performance with the value of $\mathrm{X}_{1}(0.885)$ and the indicator of $X_{3}(0.860)$. According to Jobplanet Indonesia in Triwijarnako (2016), employees who work in the government agencies are the employees who are the most satisfied with their type of work. Generation $Y$ also hopes that the leaders of the agencies can involve generation $\mathrm{Y}$, leaders have openness to them and can guide them in their work (Ohlrich 2011).

The Loading factor of the final measurement model shows that the indicators of paying attention to feedback and time of finishing the duties are the two highest indicators reflecting the motivation affecting the performance with the value of $Z_{3}(0.902)$ and indicator $Z_{5}(0.885)$. The generation $Y$ characteristics in the scope of work delivered by Solnet and Hood (2008) revealed that generation $Y$ employees want direct feedback. Brown et al. (2008) stated that $90 \%$ of generation $Y$ want jobs which offer flexible work schedules, has the spirit and energy to work, and has a passionate enthusiasm to complete their duty.

The two highest indicators that reflects performance are the responsibility as well as the effectiveness and efficiency with the $Y_{2}$ value of 0.967 and $Y_{1}$ of 0.962 . Luntungan et al. (2014) suggested that Generation $Y$ is a generation who are very expensive, but at the same time they also have very high performance (high maintenance, high performance). It means that the generation is very independent and expecting their performance to be assessed based on the results, rather than only based on the routines at the office since they master technology and use process effectiveness.

The requirement for the model to be considered to have a good validity if each latent variable with a reflective indicator has AVE $>0.5$. The analysis result shown in Table 2 shows the AVE value of each latent variable has a value of $>0.5$ and it can be considered that the PLS model meets good convergent validity requirements.

The next measurement is reliability test on the model used to prove the accuracy, consistency, and appropriateness of the instrument in measuring the construct. The reliability test by measuring composite reliability on the latent variables which have a value $>0.7$ is considered to be reliable. The research result based on Table 2 shows that all latent 
constructs have good, accurate and consistent reliability because they meet the requirements with composite reliability values for each latent construct more than 0.7 .

Table 2 - The value of average variance extracted (AVE), composite reliability

\begin{tabular}{lll}
\hline $\mathrm{n} / \mathrm{n}$ & AVE & Composite Reliability \\
\hline Job Satisfaction & 0.677 & 0.912 \\
Performance & 0.898 & 0.972 \\
Motivation & 0.735 & 0.917 \\
\hline
\end{tabular}

Table 3 - Crossloading values

\begin{tabular}{llll}
\hline $\mathrm{n} / \mathrm{n}$ & Job Satisfaction & Performance & Motivation \\
\hline $\mathrm{X} 1$ & 0.885 & 0.582 & 0.252 \\
$\mathrm{X} 2$ & 0.799 & 0.421 & 0.066 \\
$\mathrm{X} 3$ & 0.860 & 0.668 & 0.253 \\
$\mathrm{X} 4$ & 0.855 & 0.622 & 0.191 \\
$\mathrm{X} 5$ & 0.701 & 0.441 & 0.371 \\
Y1 & 0.645 & 0.962 & 0.500 \\
Y2 & 0.644 & 0.967 & 0.457 \\
Y3 & 0.643 & 0.914 & 0.375 \\
Y4 & 0.650 & 0.947 & 0.414 \\
Z1 & 0.166 & 0.235 & 0.778 \\
Z3 & 0.254 & 0.426 & 0.902 \\
Z5 & 0.333 & 0.499 & 0.885 \\
Z6 & 0.158 & 0.332 & 0.859 \\
\hline
\end{tabular}

Discriminant validity testing was done on the principle that the constructs manifest variable should not be high correlated (Ghozali 2008). The discriminant validity testing in Table 3 shows that all indicators have greater crossloading values for latent variables compared to other latent variables. It can be considered that the model has met the requirements of discriminant validity.

Table 4 - Correlation value between latent variables and $\sqrt{ }$ AVE values

\begin{tabular}{llll}
\hline $\mathrm{n} / \mathrm{n}$ & Job Satisfaction & Performance & Motivation \\
\hline Job Satisfaction & $\sqrt{\mathrm{AVE}}=0.823$ & & \\
Performance & 0.681 & $\sqrt{\mathrm{AVE}}=0.948$ & \\
Motivation & 0.285 & 0.462 & $\sqrt{ } \mathrm{AVE}=0.857$ \\
\hline
\end{tabular}

Table 4 above shows that the $\sqrt{ }$ AVE value $>$ the correlation value between latent variables which means that the model has met the discriminant validity.

Structural Model Evaluation. The bootstrapping result in Table 5 shows that satisfaction has a significant effect on the motivation at the level of $5 \%$ because the t-statistics value $>t$ table (1.96). Motivation also has a significant effect on performance at the level of $5 \%$ because the t-statistics value $>$ t-table (1.96).

Table 5 - R-square values

\begin{tabular}{ll}
\hline $\mathrm{n} / \mathrm{n}$ & $\mathrm{R}$-square \\
\hline Motivation & 0.081 \\
Performance & 0.542 \\
\hline
\end{tabular}

The structural model of Motivation produces an $\mathrm{R}$ - square value of $8.1 \%$, which means that the motivation diversity that can be explained by the model is $8.1 \%$, while the remaining $91.9 \%$ is explained by other factors outside the model. The structural model of performance produces an R- square value of $54.2 \%$, which means that the performance diversity which can be explained by the model is $54.2 \%$, while the remaining $45.8 \%$ is explained by other factors outside the model.

Hypothesis Testing. The next test in the evaluation of the inner model or structural model was conducted to see the significance of the path coefficient which shows relationship 
or effect between the latent variables in the research. In PLS, testing each relationship is done using a simulation with the bootstrapping method for path coefficients from the PLS SEM analysis which can be seen in Table 6.

Table 6 - Path coefficient and t-statistics Values

\begin{tabular}{lll}
\hline & Path coefficient & T-statistic \\
\hline Job Satisfaction $->$ Motivation & 0.285 & $2.830^{*}$ \\
Job Satisfaction $>$ performance & 0.598 & $4.572^{*}$ \\
Motivation $>$ Performance & 0.292 & $2.642^{*}$ \\
Job Satisfaction $>$ Motivation $>$ Performance & 0.681 & $5.748^{*}$ \\
\hline
\end{tabular}

Note: *) significantly affect at the level of $5 \%$ (T-statistic $>$ T-table (1.96).

The analysis result in Table 6 shows that job satisfaction has a positive or direct effect on motivation with the path coefficient value of 0.285 . This result is significant at the level of $5 \%$ because the t-statistic value $(2.830)>t$-table (1.96). This shows that the better the generation $Y$ employees' job satisfaction, the more increase the employees' motivation. In line with research conducted by Grenway (2008) which stated that there is a relationship between job satisfaction and motivation, where generation $Y$ employees who have job satisfaction will have high motivation in achieving and supporting the achievement of agency goals. Based on the results of the path coefficients, the first hypothesis in this study which states that the job satisfaction can affect the motivation in the Secretariat General of the Ministry of Agriculture is accepted.

Job satisfaction also positively and directly affects the employees' performance with a coefficient of 0.598 . This result is significant at the alpha level of $5 \%$ for the value of t-statistic (4572) > t-table (1.96). This shows that job satisfaction directly affects the performance which means that it is not intervened by the motivation. The higher the level of Generation $Y$ employees' job satisfaction, the higher the level of employees' performance given. This finding is in line with the previous research conducted by Sarittama and Noerman (2017) which stated that there is an effect of job satisfaction on the generation $Y$ employees' performance. Based on the results of the path coefficients, the second hypothesis in this study which states that job satisfaction affects the performance of the Secretariat General of the Ministry of Agriculture is accepted.

Motivation positively and directly affects the performance with a coefficient of 0.292 . This result is significant at the alpha level of $5 \%$ for the t-statistic value of $(2642)>t$-table (1.96). It indicates that the higher the $Y$ generation employees' motivation, the more increase the employees' performance level. This finding is in accordance with the previous research conducted by Sarittama and Noerman (2017) which stated that there is an effect of motivation on the generation $Y$ employees' performance. Based on the results of path coefficients, the third hypothesis of this esearch stating that motivation affects performance in the Secretariat General of the Ministry of Agriculture is accepted.

Job satisfaction on performance also has positive and direct effect with the coefficient value of 0.681 . These results are significant at the alpha level of $5 \%$ for the t-statistic value (5.748) > t-table (1.96). Thus, in improving the generation $Y$ employees' performance, there must be a close relationship between job satisfaction and motivation and between motivation and performance so that the generation $\mathrm{Y}$ employees can provide a better performance. It shows that motivation can be used as an intervening variable to affect the employees' job satisfaction in which the higher the generation $Y$ employees' job satisfaction, the more increase their motivation will be since it gives a positive and direct effect on the performance. This finding is in line with the previous research conducted by Sudrajat and Yuniawan (2016) which also showed that motivation can be act as an intervening variable to affect the job satisfaction on the employees' performance. Based on the results of the path coefficient value, the second hypothesis in this study stating that job satisfaction affects the generation $Y$ employees' performance through motivation is accepted. 


\section{MANAGERIAL IMPLICATIONS}

Based on the analysis result of the effect of generation $Y$ employees' job satisfaction on the employees' performance with motivation as intervening variable, employees' performance can be increased through job satisfaction and motivation. Some ways that can be done to improve the employees' performance are as follows:

Based on job satisfaction, the generation $Y$ employees' performance can be improved through job satisfaction by trying to increase the facilities according to the benefits and needs of $Y$ generation, especially on technology in order to obtain information about their work. Agencies can create a bookkeeping system of incoming and outgoing letters for secretariats in each bureau. Agencies can also try to create a system for employees who want to apply for leave or other employees' needs such as changes in family status, application of mutations, and application of scholarships.

Based on the motivation, employees' performance can be improved by paying attention to feedback. Agencies can create a meeting or briefing in the morning of both the scope of the agency or work unit that aims to build communication among the employees since the superior and subordinates can provide feedback or criticisms and suggestions to the problem encountered. The superior can give opportunities to the employees to share their ideas or inputs that can be useful in order to achieve the work programs that have been welldeveloped at this time.

In completing their work, the generation $Y$ employees have a responsibility not only on the process but also at the end and the implementation of the duty. In addition, generation $Y$ employees can give more attention to the work provided by reporting to the superiors if there is any problem in the work and handling the work effectively and efficiently. Such thing should be implemented in order to build a good two-way communication system between superiors and subordinates especially for $\mathrm{Y}$ generation employees. Thus, generation $\mathrm{Y}$ employees have space to express their opinions. Two-way communication also applies confirmation system that all things that involve decision-making must be confirmed by superiors and subordinates.

\section{CONCLUSION}

In improving the generation $\mathrm{Y}$ employees' performance, there must be a strong relationship between the job satisfaction and motivation in order to produce the best performance from these employees. Results from this research showed that job satisfaction affects the employees' performance through motivation, resulting in an improved job satisfaction which will increase the employees' motivation. This will lead to the improved generation Y employees' performance at the Secretariat General of the Ministry of Agriculture. Motivation can function as an intervening variable to affect the employees' job satisfaction on their performance where the higher the generation $Y$ employees' job satisfaction, the more increase their motivation since it has a direct effect on the generation $Y$ employees' performance at the Secretariat General of the Ministry of Agriculture.

\section{RECOMMENDATIONS}

Future research can add samples besides the generation $\mathrm{Y}$, such as to generation $\mathrm{X}$ in order to find out the differences of the characteristics in working expectations of generation $X$ and generation $\mathrm{Y}$ in government agencies and analyzing the characteristics of generation $\mathrm{X}$ and $Y$ to know what is the dominant thing about job satisfaction and motivation of the two generations.

Adding other variables outside the variables that have been studied that affect the employees' performance, such as leadership style and organizational culture. In addition, the same research can be done with different objects, such as in private companies because private companies are more varied in terms of human resources than the government agencies. 


\section{REFERENCES}

1. [BKKBN] Badan Kependudukan dan Keluarga Berencana Nasional. 2017. Usia Pernikahan Ideal 21-25 tahun. [diakses pada tanggal 8 Mei 2018].

2. [BPS] Badan Pusat Statistik. 2017. Jumlah Angkatan Kerja Diatas Usia 15 Tahun. [diakses 10 Desember 2017].

3. Barnard Cl. 1938. The Functions of The Executive. Cambridge (US): Mass Harvard University Press.

4. Beu D and Buckley MR. 2001. The Hypothesized Relationship Between Accountability and Ethical Behavior. Journal of Business Ethics. 34: 57-73.

5. Brown et al. 2008. Generation $Y$ in The Workplace. Journal of HR Management. Texas (US): The Bush School Texas University.

6. Gallup. 2016. State of the American Workplace. New Jersey (US): Gallup, Inc.

7. Ghozali I. 2008. Aplikasi Analisis Multivariate dengan Program SPSS. Semarang (ID): Badan Penerbit Universitas Diponegoro.

8. Gibson, Ivancevich dan Donnelly. 2009. Organisasi. Terjemahan Edisi Ke Lima. Jakarta (ID): Erlangga.

9. Grenway B. 2008. The Relationship Between Employee Motivation and Job Satisfication of African-American Human Service Employees. ProQuest Dissertations and Theses, UMI Number: 3291476.

10. [KEMENPAN RB] Kementerian Pendayagunaan Aparatur Negara dan Reformasi Birokrasi.2016. Laporan Akuntabilitas Kinerja Instansi Pemerintah (LAKIP) Tahun 2016. Jakarta (ID): Kemenpan \& RB.

11. [KEMENTAN] Kementerian Pertanian. 2017. Laporan Akuntabilitas Kinerja Sekretariat Jenderal Tahun 2017. Jakarta (ID): Kementerian Pertanian.

12. Kupperschmidt BR. 2000. Multigeneration employees: Strategies for Effective Management. The Health Care Manager.19:65-76.

13. Luntungan IA, Hubeis VS, Sunarti E, dan Maulana A. 2014. Strategi Pengelolaan Generasi Y di Industri Perbankan. Jurnal Manajemen Teknologi. 13(2): 219-240.

14. Mangkunegara AP. 2009. Manajemen Sumber Daya Manusia. Bandung (ID): PT. Remaja Rosdakarya.

15. Marhari FJ, Amin HS, dan Utomo. 2013. Faktor-Faktor yang Berpengaruh Terhadap Kinerja Pegawai Badan Lingkungan Hidup Provinsi Kalimantan Timur. Jurnal Administrasi Reform. 1(2): 402-412.

16. McClelland DC. 1961. The Achieving Society. New York (US): D. Van Nostrand Company, Inc.

17. McClelland, Atkinson, Clark, and Lowell. 1953. The Achievment Motive. New York (US): Halsted Press.

18. Nawawi H. 2001. Manajemen Sumber Daya Manusia untuk Bisnis yang Kompetitif. Cetakan Keempat. Yogyakarta (ID): Penerbit Gadjah Mada University Press.

19. Niemiec S. 2000. Finding Common Ground For All Ages. SDM: Security Distributing \& Marketing. 30 (3): 81.

20. Oblinger D and Oblinger J. 2005. Is It Age or IT: First Steps Toward Understanding the Net Generation, dalam DG. Oblinger dan JL. Oblinger (ed.). Educating the Net Generation. (US): EDUCAUSE.

21. Ohlrich K. 2011. Analysing Corporate Social Responsibility's Impact on Employee Attraction and Retention With a Focus on Generation Y. [Dissertation]. Fielding Graduate University.

22. Panggalih B dan Zulaicha R. 2012. Pengaruh Kepuasan Kerja Terhadap Organizational Citizenship Behavior dengan Motivasi Kerja Sebagai Variabel Intervening Pada Karyawan PT. Telkom Tegal. Performance Business and Mnagament Journal UNSOED. 16(2): 1-6.

23. Prawirosentono S. 2008. Manajemen Sumber Daya Manusia Kebijakan Kinerja Karyawan. Yogyakarta (ID): BPFE. 
24. Rivai V dan Basri AFM. 2005. Performance Appraisal; Sistem yang Tepat Untuk Menilai Kinerja Pegawai dan Meningkatkan Daya Saing Instansi Pemerintah. Cetakan Pertama, PT Raja Grafindo Persada, Jakarta.

25. Robbins SP and Judge TA. 2009. Organizational Behavior. $13^{\text {th }}$ Edition. New Jersey (US): Pearson Education, Inc., Upper Saddle River.

26. Robbins SP. 2006. Perilaku Organisasi. Edisi Bahasa Indonesia (alih bahasa Drs. Benjamin Molan). Klaten (ID): PT Int An Sejati.

27. Sajjadi A, Cen SB, and Castillo LC. 2012. Generational Differences in Work Attitudes. [thesis]. Swedia (SE): Jonkoping University.

28. Sarittama NT dan Noerman. 2017. Strategi Kepemimpinan, Motivasi Kerja dan Kompensasi terhadap Kepuasan Kerja serta Dampaknya pada Kinerja Karyawan Generasi Y PT. Bank BRI Wilayah I Jakarta. Jurnal Riset Perbankan Manajemen dan Akuntansi. 1(1): 45-53.

29. Solnet D and Hood A. 2008. Generation $Y$ as Hospitality Employees: Framing a research agenda. Journal of Hospitality and Tourism Management. 15: 59-68. Doi 10.1375/jhtm.

30. Sopiah. 2008. Perilaku Organisasi. Yogyakarta (ID): Andi Offset.

31. Sudrajat WA dan Yuniawan A. 2016. Analisis Pengaruh Kepuasan Kerja Terhadap Kinerja Karyawan Dengan Motivasi Kerja Sebagai Varaibel Intervening. Diponegoro Journal of Management. 5(3): 1-9.

32. Tolbize A. 2008. Generational Differences in The Workplace. Research and Training Center on Community Living. Minnesota (US): University of Minnesota. 1-21.

33. Triwijarnako R. 2016. Benarkah PNS Merupakan Karyawan Paling Puas Dengan Pekerjaannya. (July 22, 2016). Retrieved September 16, 2018 from Marketeers.com: http://marketeers.com/benarkah-pns-merupakan-karyawan-paling-puas-denganpekerjaannya/. 